\title{
A Karyological Study on Four Species of Mediterranean Gobiid Fishes
}

\author{
Guillermo Thode, Jesus Cano and $M^{a}$ Carmen Alvarez \\ Departamento de Genética, Facultad de Ciencias, Universidad de Málaga, España
}

Received February 12, 1981

The study of the family Gobiidae (Pisces, Perciformes) has been introduced due to the interest it arises inside the order Perciformes, since constitutes a group of controverted characteristics both in its taxonomical and evolutive situations as well as in the results from previous studies (Chen and Ebeling 1971, Chiarelli and Capanna 1973, Denton 1973, Arai et al. 1974, Manna and Prasad 1974, Arai and Sawada 1975, Ojima et al. 1976, Khuda-Bukhsh 1978).

About fifty species from this suborder belonging to different areas have been studied karyologically up to now and the results show a range in the chromosome number from 40 (Arai and Kobayasi 1973, Arai and Sawada 1974) to 62 (Nogusa 1955), being $2 \mathrm{n}=44$ as the most common in this group (Nishikawa et al. 1974). With regard to the description of the karyotype, using different techniques and different nomenclature, the arm number (FN) which has been reported fluctuates from 40 (Arai and Kobayasi 1973, Arai and Sawada 1974) to 98 (Nishikawa et al. 1974). In this group, 3 cases of sex chromosomal determinism have been reported (Nogusa 1955, Subrahmanyam 1969, Arai and Sawada 1974).

Relating to their cell DNA content the only available data came from Hinegardner (1968) and Hinegardner and Rosen (1972) who asign $1.4 \mathrm{pg}$. for Gobius sadanundio and another unidentified goby and $1.2 \mathrm{pg}$. for Typhlogobius californiensis.

\section{Material and methods}

The species under study were: Gobius cobitis (Pallas 1811), G. paganellus (Linneo 1758), G. bucchichi (Steindachner 1870) and G. niger (Linneo 1758); Pisces Perciforms. The fishes were collected in the south-mediterranean coast of Spain, littoral of Málaga, and classified according to Lozano y Rey (1952) and Tortonese (1975). Chromosome preparations were made in accordance with the technique reported by Alvarez, Cano and Thode (in press). Chromosomes from several metaphases (Table 1) were counted and measured to determine the diploid number of each species and the mean length of each chromosome to elaborate their idiograms. Arm-ratio (AR) of the chromosomes based on 25 mitoses was determined according to Levan et al. (1964), considering the subtelocentric chromosomes as monoarmed. Nuclear DNA content was measured according to Fox (1969), as it has been previously described by Alvarez, Cano and Thode (in press). 

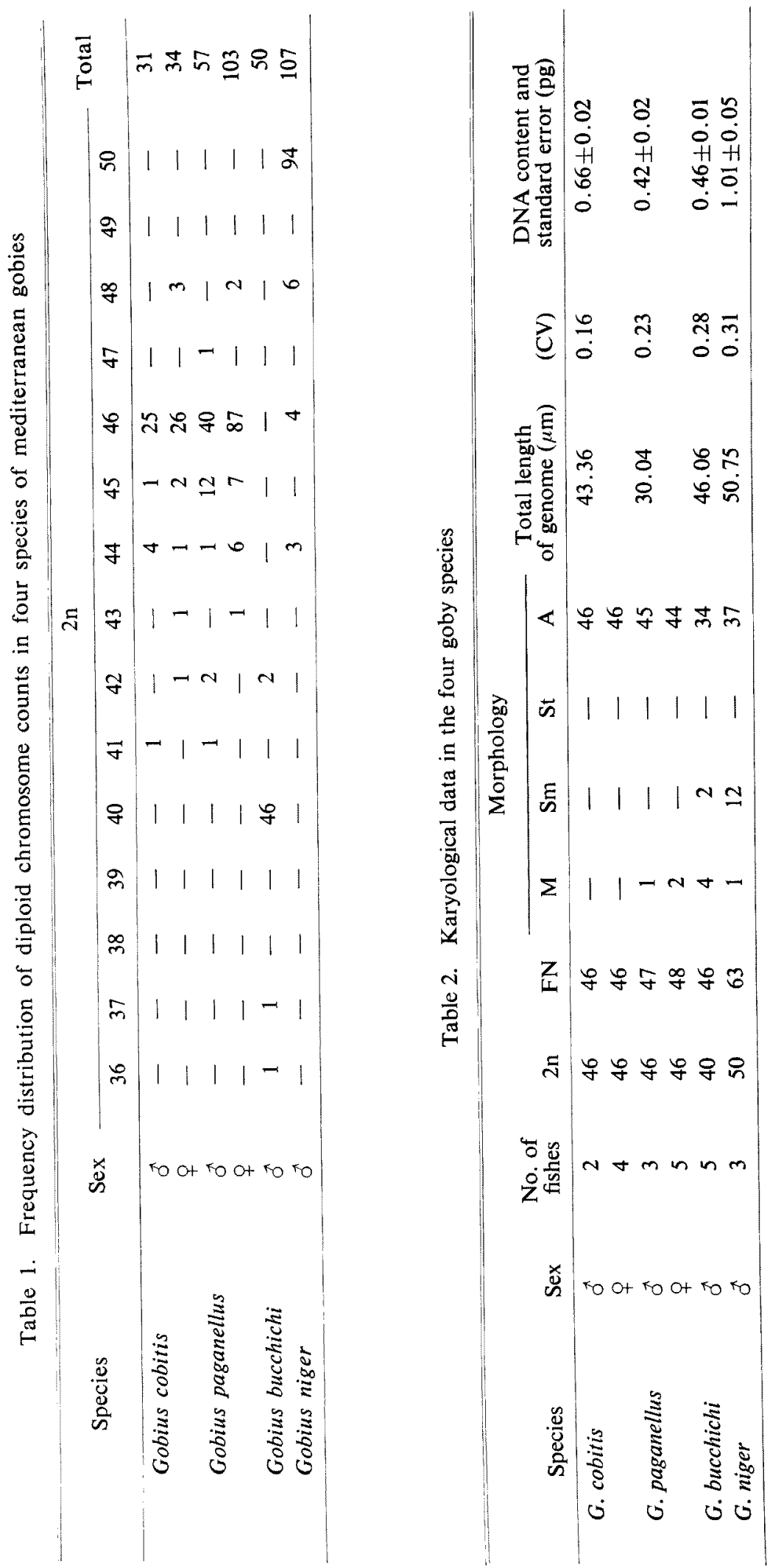


\section{Results and discussion}

The metaphase plates and karyotypes of the four species are shown in Figs. 1, 2 and 3, and their respective idiograms in Fig. 4. The numerical and morphological data are summarized in Table 2.

The karyological data cited about the species of suborder Gobioidei up to now are rather incomplete, most of them only include the chromosome and the arm numbers, although they do not always coincide. In this case, our results relating to chromosome and arm number of $G$. paganellus $(2 \mathrm{n}=46, \mathrm{FN}=47$ in male and $\mathrm{FN}=48$ in female $)$ and $G$. niger $(2 \mathrm{n}=50, \mathrm{FN}=63)$ disagree with those given by

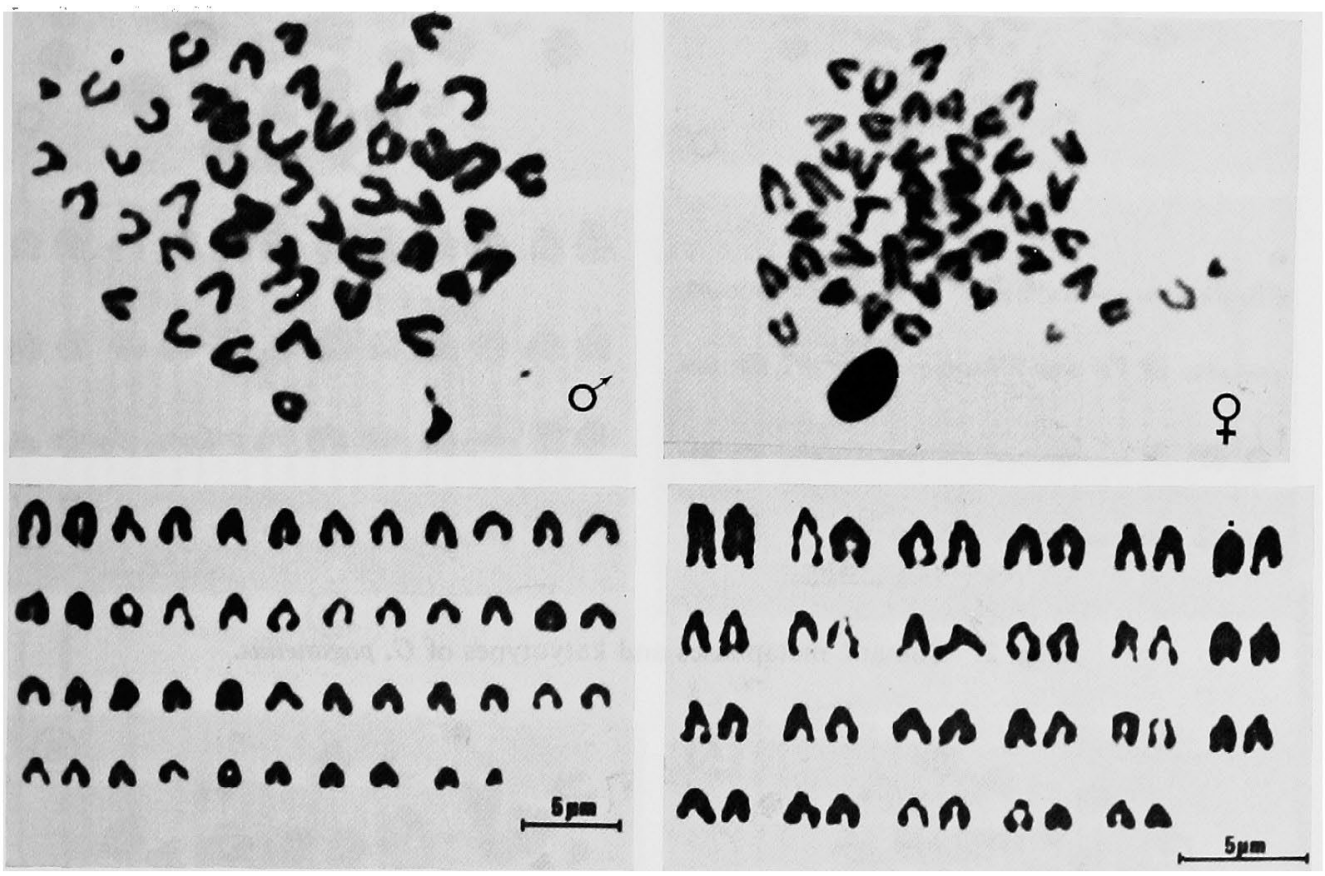

Fig. 1. Somatic metaphases and karyotypes of G. cobitis.

Cataudella et al. (1973) which asign $2 \mathrm{n}=45, \mathrm{FN}=50$ (unknown sex) and $2 \mathrm{n}=48$, $\mathrm{FN}=56$ respectively for each species.

According to numerous authors (Ohno et al. 1969, Ebeling and Chen 1970, Ohno 1970, Chen 1971), we adopt that the ancestral karyotype of fishes consists of $2 n=48$ subequal acrocentric chromosomes, therefore $\mathrm{FN}=48$, having a haploid DNA content about $20 \%$ with regard to mammals $(1.3 \mathrm{pg})$. Also, we have realized in many reports that in the same genus, the specialization runs parallel to a decrement in chromosome number as well as to an increase in the arm number and to a diminution in the nuclear DNA content (Hinegardner and Rosen 1972).

Considering as a whole the different karyological parameters in the four species we have determined (Table 2) and due to the little correlation found among them, we can suggest that they do not constitute a single phylogenetic lineage. In this way, we propose the following diagram (Fig. 5) to explain their evolutionary relationship. 
In order to find out a plausible explanation of the evolutionary tree, we have been forced to appeal to two hypothetic forms derived from the ancestral one.

The step from the ancestral to the hypothetic A could be through the loss of a pair of chromosomes, possibly compossed by a less important genetic material or
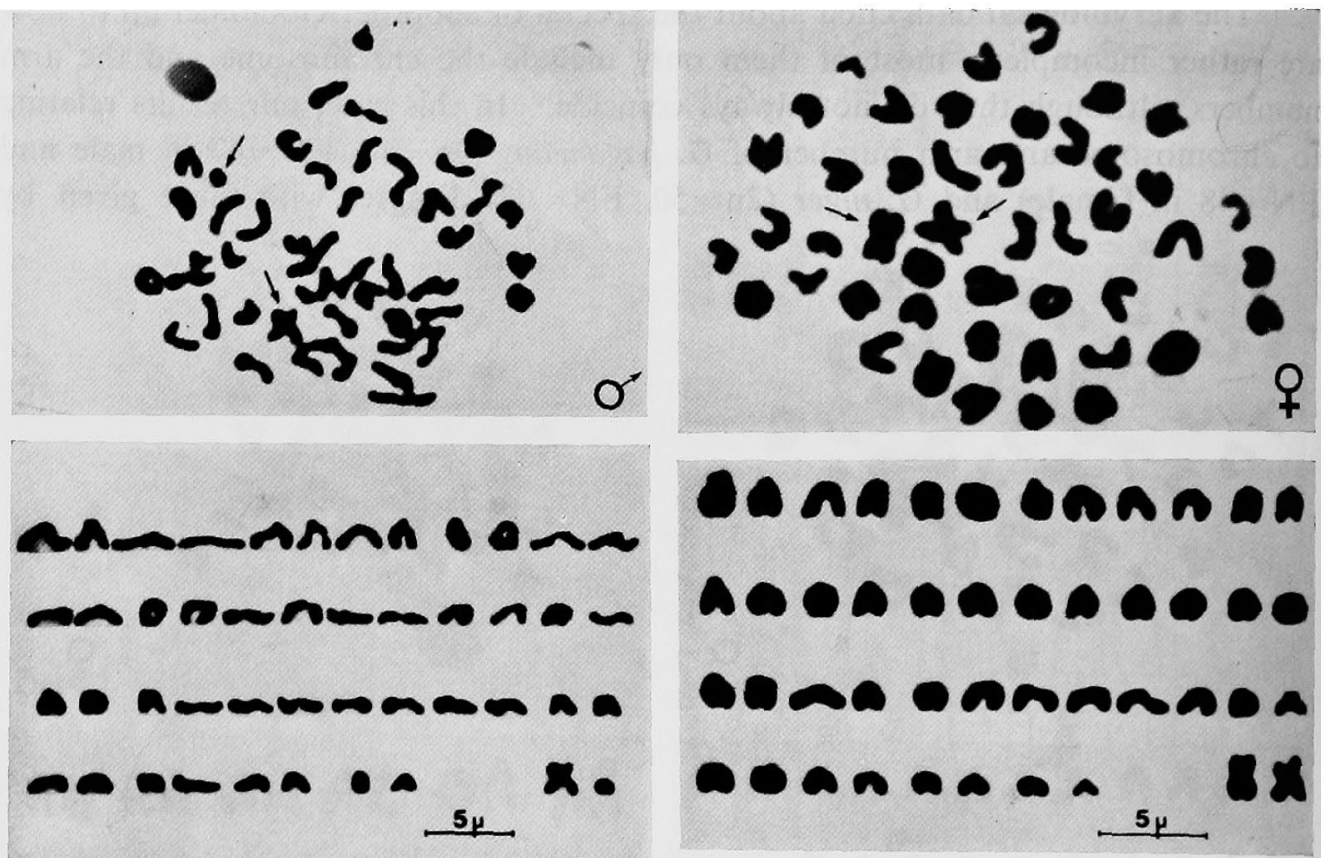

Fig. 2. Somatic metaphases and katyotypes of G. paganellus.

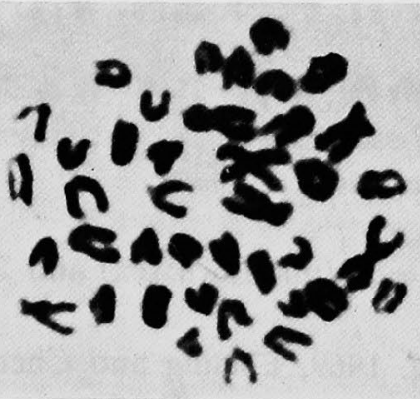

(A)

\section{$\sin$ in in}

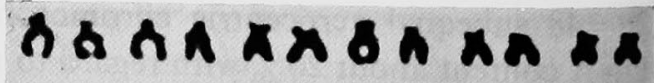

Do ol on no on do

as in ar as adon

a on un a a an sm

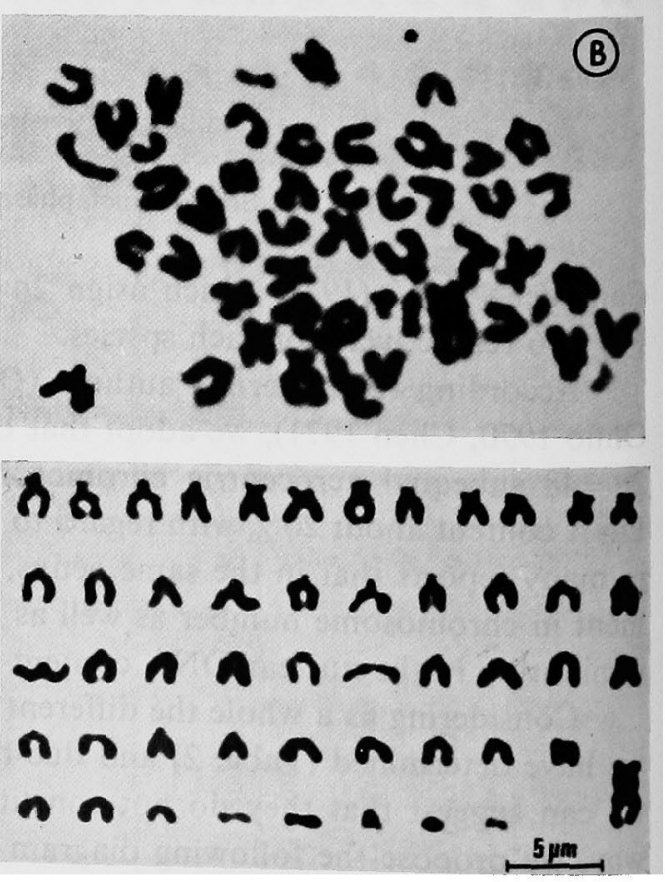

Fig. 3. Somatic metaphases and karyotypes of: (A) G. bucchichi and (B) G. niger. 
through the centric fusion of two pairs with a subsequent pericentric inversion.

The G. cobitis might came from this hypothetic A because of the reduction in its DNA content; in his turn, G. bucchichi would be originated by the same via of the DNA reduction, through three centric fusions, so that the biarmed chromosomes are approximately twice uniarmed ones (Fig. 4); in this situation the total length of the genome is actually unaffected.

The G. paganellus could proceed from the G. cobitis by a pericentric inversion; nevertheless it is more probable that the former comes from the ancestral by means of a centric fusion, because the length of the metacentric chromosome is remarkably bigger than that of the acrocentric ones (Fig. 4); in any case there is besides a reduction in the DNA content.
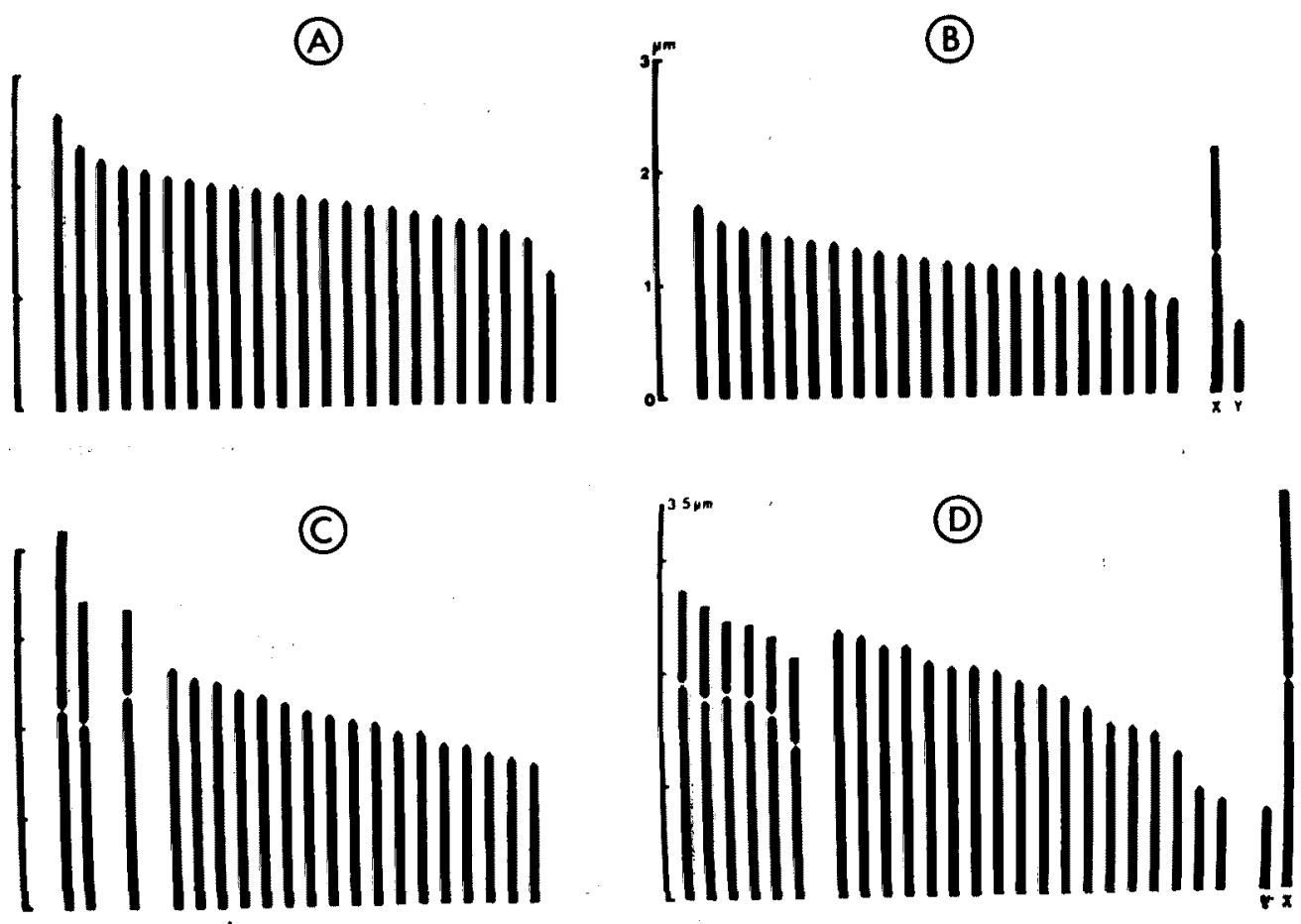

Fig. 4. Idiograms of: (A) G. cobitis, (B) G. paganellus, (C) G. bucchichi and (D) G. niger.

The step from the ancestral to the hypothetic B could happen by the increase of a pair of chromosomes, due probably to the inversion of a pair which would give rise to biarmed chromosomes with a further centric fission in them.

The $G$. niger might be derived from the hypothetic B by pericentric inversions as well as by other rearrangements; but in this lineage there is a slight reduction in DNA content.

On the basis of the variation coefficient (CV: standard deviation divided by the mean chromosomal length, which expresses the heterogeneity grade in the sample) (Hinegardner and Rosen 1972) we can consider G. cobitis and G. niger as the less and most karyologically differentiated species, which helps to confirm our hypothesis.

Comparing the data of this four species with those given by other workers, in 
52 species belonging to the suborder Gobioidei, we have checked out that their chromosomal complements lie between the limits previously established ( $2 n=40$ to 62$)$ and that this wide variation as well as the one found in the scarce available data about DNA content, support a rapid evolutionary radiation inside the group, which has not allowed that clearly phenotypical differences could be expressed.

Relating to the DNA content values we have observed from the available data that for the Gobioidae, they range between $0.42 \mathrm{pg}$. for G. paganellus and 1.40 for G. sadanundio (Hinegardner and Rosen 1972) which means a very wide dispersion in relation to the rest of the families of Perciformes, where these values are more homogeneous.

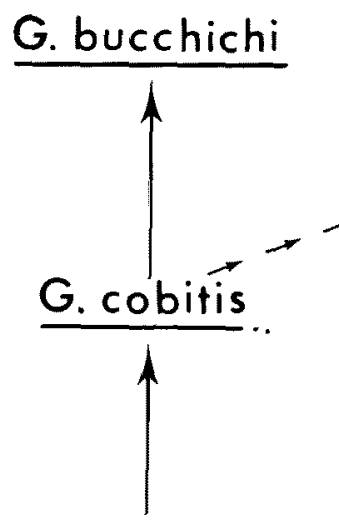

Hypothetic A
G. paganellus

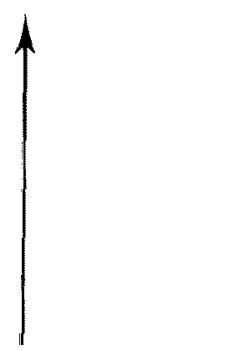

Ancestral

\section{G. niger}

Fig. 5. Evolutionary tree of the goby species studied in this report.

In this situation we are not able to fit this family in the distribution of Teleosts given by Hinegardner and Rosen (1972) since among this group, some species show values noticeably over and under the modal one $(\sim 1 \mathrm{pg}$.).

Concerning to the observation of heteromorphic chromosomes in the male karyotype of $G$. paganellus and $G$. niger, it suggests the already known sex chromosomal mechanism XX/XY.

In order to identify the sexual pair we have taken into account Mittwoch's criteria (1967), who considers that sex chromosomes in gonochoristic species usually differ by their shape and size from the rest of the complement. The smallest chromosome in both species has been considered by exclusion as the chromosome $\mathrm{Y}$, which would represent a derived condition through degeneration from the $X$. However it is essential to check it in the female karyotype of the G. niger, to study the meiotic process in both species; and to apply finally chromosome $\mathrm{C}$-banding techniques.

In any case our findings of sexual chromosomes have been reinforced by other reports in the gobioidei, previously cited in the introduction. 


\section{Summary}

Somatic chromosomes of 4 species of mediterranean gobies are examined. Cells from gills, kidney and spleen were used after treatment with colchicine. The haploid DNA content in picograms and chromosomal number values were respectively: Gobius cobitis, $0.66,2 \mathrm{n}=46 ;$ G. paganellus, $0.71,2 \mathrm{n}=46 ;$ G. bucchichi, 0.46 , $2 n=40 ; G$. niger, $0.68,2 n=50$. The chromosome number of $G$. bucchichi and the DNA values of the four species are given for the first time. Only G. paganellus and $G$. niger showed sexual heteromorphic chromosomes. An evolutionary diagram for the four species as well as a sex determination mechanism $\mathrm{XX} / \mathrm{XY}$ are proposed.

\section{Acknowledgements}

The authors are grateful to Miss Amparo Maldonado for her collaboration in this work.

\section{References}

Alvarez, M. C., Cano, J. and Thode, G. DNA content and chromosome complement of Chromis chromis (Pommacentridae, Perciformes). (in press).

Arai, R., Katsuyama, I. and Sawada, Y. 1974. Chromosomes of Japanese Gobioid fishes II. Bull. Natn. Sci. Mus. Tokyo 17(4): 269-279.

— and Kobayasi, H. 1973. A chromosome study on thirteen species of Japanese Gobiid fishes. Japan J. Ichthyol. 20(1): 1-6.

- and Sawada, Y. 1974. Chromosomes of Japanese Gobioid fishes I. Bull. Natn. Sci. Mus. Tokyo 17(2): 97-105.

- and - 1975. Chromosomes of Japanese Gobioid fishes III. Bull. Natn. Sci. Mus. Tokyo 1(4): 225-239.

Cataudella, S., Civitelli, M. V. and Capanna, E. 1973. The chromosomes of some mediterranean Teleosts: Scorpaenidae, Serranidae, Labridae, Blennidae, Gobiidae (Pisces-Scorpeniformes, Perciformes). Boll. Zool. 40: 385-389. Roma.

Chen, T. R. 1971. A comparative chromosome study of twenty killifish species of the genus Fundulus (Teleostei: Cyprinodontidae). Chromosoma (Berl.) 32: 436-453.

- and Ebeling, A. W. 1971. Chromosomes of the Goby fishes in the genus Gillichthys. Copeia 1: 171-174.

Chiarelli, A. B. and Capanna, E. 1973. Cytotaxonomy and Vertebrate Evolution. Academic Press, London-New York.

Denton, T. E. 1973. Fish Chromosome Methodology. Charles C. Thomas publish. U. S. A.

Ebeling, A. W. and Chen, T. R. 1970. Heterogamety in Teleostean fishes. Trans. Amer. Fish. Soc. No. 1, 99: 131-138.

Fox, D. P. 1969 . Some characteristics of the cold hydrolysis technique for staining plant tissues by Feulgen reaction. J. Histochem. Cytochem. 17: 266.

Hinegardner, R. T. 1968. Evolution of cellular DNA content in Teleost fishes. Amer. Natur. 102(928): 517-523.

- and Rosen, D. E. 1972. Cellular DNA content and the evolution of Teleostean fishes. Amer. Natur. 106, No. 951.

Khuda-Bukhsh, A. R. 1978. Somatic chromosomes of an estuarine fish, Trypauchen vagina (Fam. Gobiidae) from Sagar Island, West Bengal, India. Repr. from "Curr. Sci". 47(4): 137138.

Levan, A., Fredga, K. and Sandberg, A. A. 1964. Nomenclature for centromeric position on chromosomes. Hereditas 52: 201.

Lozano y Rey, L. 1952. Peces Fisoclistos. Serie de Ciencias Naturales-T. XIV. Real Acad. de 
Cienc. Exact., Fisic. y Natur. Madrid.

Manna, G. K. and Prasad, R. 1974. Chromosome analysis in three species of fishes belonging to family Gobiidae. Cytologia 39; 609-618.

Mittwoch, U. 1967. Sex Chromosomes. Academic Press, New York and London.

Nogusa, S. 1955. Chromosome studies in Pisces IV. The chromosomes of Mogrunda obscura (Gobiidae), with evidence of male heterogamety. Cytologia 20: 11-18.

Nishikawa, S., Amaoka, K. and Nakanishi. K. 1974. A comparative study of chromosomes of twelve species of Gobioid fishes in Japan. Japan. J. Ichthyol. 21(2): 61-71.

Ohno, S. 1970. The enormous diversity in genome sizes of fish as a reflection of nature's extensive experiments with gene duplication. Trans. Amer. Fish. Soc. 99(1): 120-130.

-, Muramoto, J., Stenius, C., Christian, L., Kittrell, W. A. and Atkin, N. B. 1969. Microchromosomes in Holocephalian, Chondrostean and Holostean fishes. Chromosoma (Berl.) 26: $35-40$.

Ojima, Y., Ueno, K. and Hayashi, M. 1976. A review of the chromosome numbers in fishes. La Kromosomo II-1 : 19-47.

Post, A. 1965. Different investigations of the chromosome numbers of fresh water Teleosts. $Z$. Zool. Syst. Evolutions-Forsch. 3: 47-93.

Subrahmanyam, K. 1969. A karyotype study of the estuarine fish Boleophthalmus boddaerti (Pallas) with calcium treatment. Current Science 38: (18)437-439.

Tortonese, E. 1975. Fauna d'Italia-Osteichthyes-pesci ossei-. Ed. Calderini. Bologna.

Note added to the proof:

G. bucchichi should be replaced by G. fallax (Sarato 1889) due to a wrong classification (Communicated by Dr. M. Carmen Alvarez (November 17, 1982)). 